\title{
Morphological characteristics and nutritional value of binthe kiki, a local maize variety from Gorontalo, Indonesia
}

\author{
JUSNA AHMAD ${ }^{1}$, NOVRI YOULA KANDOWANGKO ${ }^{1, \boldsymbol{}}$, MARGARETHA SOLANG ${ }^{1}$, ERWIN NAJAMUDDIN $^{2}$ \\ ${ }^{1}$ Department of Biology, Faculty of Mathematics and Natural Sciences, Universitas Negeri Gorontalo. Jl. Jenderal Sudirman No. 6, Kota Gorontalo \\ 96128, Gorontalo, Indonesia. Tel./fax.: +62-435-821-125, ^email: novrikandowangko@ung.ac.id. \\ ${ }^{2}$ Center for Assessment and Technology of Agricultural of Gorontalo. Jl. Moh. Van Gobel No. 270, Iloheluma, Tilongkabila, Bone Bolango 96119, \\ Gorontalo, Indonesia
}

Manuscript received: 5 March 2021. Revision accepted: 29 July 2021

\begin{abstract}
Ahmad J, Kandowangko NY, Solang M, Najamuddin E. 2021. Morphological characteristics and nutritional value of binthe kiki, a local maize variety from Gorontalo, Indonesia. Biodiversitas 22: 3523-3529. Gorontalo is among the coastal areas in Tomini bay with diverse varieties of local maize. Despite that, the population of local maize has seen a steady decline over the years. A literature study reports that local maize has adapted well to the environment in which it grows. Local maize is also hailed by the commu nity as a source of food, animal feed, and the main ingredient of traditional medicines. The present study aims to investigate the morphological characteristics and nutritional value of binthe kiki local maize variety. Employing a quantitative descriptive method, the data of morphological characteristics were collected by referring to the maize descriptor guidelines, while the data of the nutritional value of maize kernels (regarding the proximate and mineral contents) were analyzed by referring to the Indonesian National Standard and Association of Official Agricultural Chemists (AOAC) standards. The findings show that the morphological characteristics of binthe kiki variety are as follows: (i) an average plant height of $161 \mathrm{~cm}$; (ii) each stalk has three cobs with an average height of $119 \mathrm{~cm}$; (iii) an average stalk circumference of $6.35 \mathrm{~cm}$; (iv) an average of 12 leaves per stalk; (v) $71.12 \mathrm{~cm}$ of an average length of leaves; (vi) $5.21 \mathrm{~cm}$ of an average width of leaves; (vii) the direction of the leaf blade, on average, is slightly curved; (viii) the average leaf tip is pointed; (ix) an average cob length of $8.4 \mathrm{~cm}$; (x) an average cob diameter of $2.74 \mathrm{~cm}$; (xi) an average cob weight (without husk) of $0.054 \mathrm{~kg} / \mathrm{cob}$; (xii) an average of 24 kernels per row; (xiii) an average weight per 1000 kernels of 145 gram. Binthe kiki variety has high contents of protein, carbohydrate, zinc, and calcium, yet it is low in fat contents compared to other varieties.
\end{abstract}

Keywords: Agricultural products, binthe kiki maize, Gorontalo, local varieties, small-sized corn

\section{INTRODUCTION}

Binthe kiki, or "small-sized corn" in Gorontalo language, is an almost extinct local maize variety native to Gorontalo. The variety is officially registered in the Center of Plant variety Protection in 2018 as a protected variety (PPVPT 2018). Compared to other varieties, the binthe kiki local variety is superior in terms of 70 days after planting (DAP) harvest period, low water content, density, and longevity. Generally, local farmers plant the variety for personal consumption, not for commercial use. In the region, the kernels of binthe kiki variety have been widely used as ingredients for traditional food, such as boiled corn, balobinthe (traditional corn rice), and binthe biluhuta (corn soup) (Peraturan Daerah Provinsi Gorontalo 2015). It is commonly accepted that consuming such a product can delay hunger on account of high carbohydrate and protein contents in maize as one of the main staples of the Indonesian community (Suarni and Widowati 2017).

The challenge to the development of binthe kiki variety lies in the limited scope of the community that practices the variety cultivation in their own land. Despite the problems posited by such a condition, some farmers still cultivate local maize variety amid the hybrid variety as the dominant variety of maize in the region. The farmers claim that binthe kiki has a quicker harvest duration than the hybrid maize variety. The local variety is cultivated and harvested by the farmers for personal consumption. Efforts to cultivate and develop the local variety are still much needed as the means of preservation of the germplasm of the native maize variety of Gorontalo. The biodiversity of germplasm is considered one of the national treasures that require preservation as the nation's genetic source in assembling new plant varieties. This is in line with Yasin et al (Yasin et al. 2017), who opines that local variety is one of the genetic components to assemble a superior plant variety. Among the most common locally-cultivated maize varieties in Sulawesi island is Mesi variety from Sigi District, Central Sulawesi Province (Yasin et al. 2018); Batarakoasa, Gowa, Pangkajene, and Batarakamu waxy maize cultivars (Wawo et al. 2019); local waxy maize from Ampana Sub-district, Tojo Una-Una District (Yusran and Maemunah 2011); Manadonese yellow variety (Landeng et al. 2017); and Momala local variety from Gorontalo (Suleman et al. 2019).

The maize varieties have different functions in different regions. In most developing countries, maize is often used as one of the main staples for daily consumption. In developed countries, however, maize kernels are mostly used as industrial raw materials for products, including frying oil, syrup, starch, animal feed formulation, as well as composing materials of bioethanol/bioenergy sources. The 
use of maize as an ingredient for medicine has been growing steadily. For instance, the filtrate of maize kernels mixed with rhizomes from Curculigo pilosa is used as a traditional medicine for diabetes mellitus (Karigidi and Olaiya 2019). The genotype of orange, yellow maize is well-known as the source of provitamin A carotenoid, a Vitamin A precursor that plays a major role in boosting overall health and preventing diseases (Hwang et al. 2016).

Maize has a high chance of cross-pollination due to the female flowers that act as cobs and male flowers acting as panicles that are located in one plant (or monoecious). Kahiu et al. 2013 reported that in inbred strains, tassel anthesis occurred 2.7 - 4.0 days before the appearance of corncob hairs. Furthermore, (Dahlan, 2018), stated that one panicle can produce millions of pollens which is easily carried by the wind. The panicle begins to produce pollen 1-3 days before the cob hair discharges. Cross-pollination in maize can reach $95 \%$ or more. If the practice of cultivating binthe kiki corn is carried out in locations adjacent to hybrid corn, it is likely that cross-pollination will occur between binthe kiki corn and hybrid corn.
Hybrid maize can provide higher seed yields than freesigned maize, but once farmers plant a new seed, they must purchase new seeds to maintain their potential seed productivity. On the other hand, the area of Gorontalo has its own local maize germplasm which has adapted well to its habitat. Despite that, maize cultivation is on the brink of extinction due to the ignorance of the variety's potential nutritional values and other advantages. On that ground, the article delves into exploring the morphological characteristics and nutritional value of binthe kiki maize variety native to Gorontalo.

\section{MATERIALS AND METHODS}

\section{Samples collection}

The samples of binthe kiki maize variety were collected from the cultivation land in two sites in Gorontalo District, Gorontalo Province, Indonesia, i.e., Biluhu Barat Village of Batudaa Sub-district, and Juria Village of Bilato Subdistrict (Table 1, Figure 1).

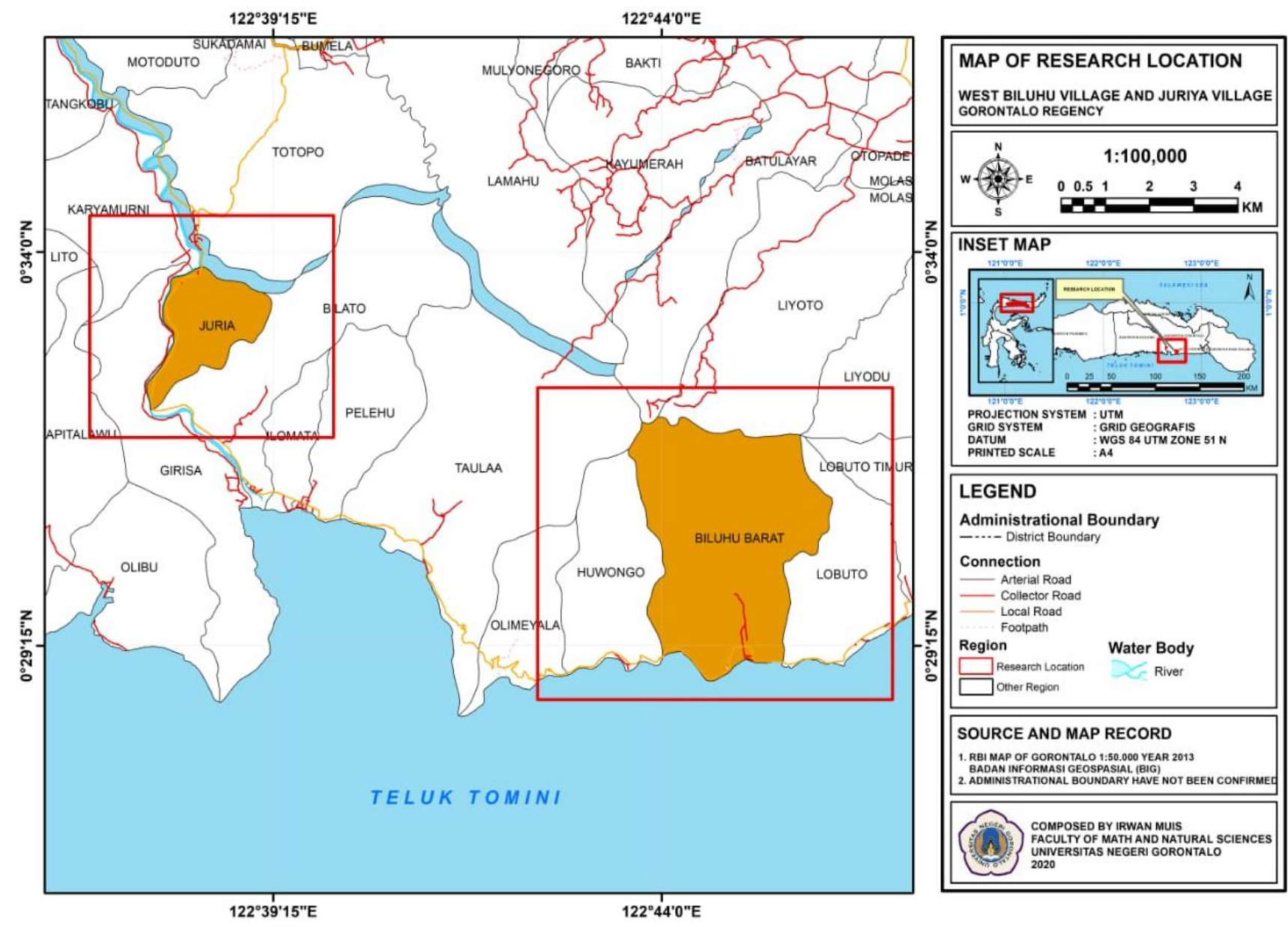

Figure 1. Sample collection site in Biluhu Barat Village of Batudaa Sub-district and Juria Village of Bilato Sub-district, Gorontalo District, Gorontalo Province, Indonesia

Table 1. Sites of sample collection and its cultivation status 


\begin{tabular}{lll}
\hline Sample site & Status & Coordinate \\
\hline Village of Bilihu Darat, Sub-district of Batudaa, District Gorontalo & Rarely & $0^{\circ} 28^{\prime} 50^{\prime \prime}-0^{\circ} 32^{\prime} 0^{\prime \prime} \mathrm{N} ; 122^{\circ} 43^{\prime} 35^{\prime \prime}-122^{\circ} 46^{\prime} 03^{\prime \prime} \mathrm{E}$ \\
Village of Juria, Sub-district of Bilato, District of Gorontalo & Rarely & $0^{\circ} 32^{\prime} 05^{\prime \prime}-0^{\circ} 33^{\prime} 48^{\prime \prime} \mathrm{N} ; 122^{\circ} 37^{\prime} 45^{\prime \prime}-122^{\circ} 39^{\prime} 15^{\prime \prime} \mathrm{E}$ \\
\hline
\end{tabular}

\section{Research methods}

This study relied on an observation method to gather the morphological characteristic data; it was done by observing the condition of the plant in the cultivation land. The seeds were then collected and re-planted in the experiment garden of the Board of Agricultural Technology Research in Gorontalo to observe the plant's morphological characteristics. The study referred to the description guidelines that consist of qualitative characters (color, shape, and direction of the leaf blade), quantitative characters (stalk height, cob height, stalk diameter, number of leaves, leaves average length, leaves width, axillary bud, leaves tip shape, the weight of cob with husk, the weight of huskless cob, cob length, cob diameter, number of kernels per row, and weight per 1000 kernels) (IBPGR 1991); Budiarti et al. 2004). Royal Horticultural Society Color Chart was used to standardize the color. Further, a quantitative method was involved in analyzing the proximate of the nutritional values. A specific method that is based on the Indonesian National Standard (Henceforth, $\mathrm{SNI}$ ) was used to examine the proximate content (water, ash, fat, protein, crude fiber, and carbohydrate); the method is recommended by the Association of Official Analytical Chemists (AOAC) in 2005 (Murniningsih et al. 2018). The measurement of the maize kernels' nutritional values was conducted in the Board of Post-Harvest Crops in Bogor.

\section{Research procedures}

\section{Morphological characteristics}

The morphological characteristics of the maize are the quantitative characters measured with procedures by referring to the descriptor guidelines (IBPGR 1991); Budiarti et al. 2004) as follows: Stalk height (cm): measured from the stem base above the ground to the base of panicles. The measurement was conducted after $50 \%$ of the population was in anthesis period (the flower blooms perfectly). Cob height $(\mathrm{cm})$ : measured from the ground level to the node where the top cob grows. The measurement was conducted after the plants were in the close-to-ripeness stage. The ratio between the height of top cob and height of plant: the height of the top cob was measured from the ground level and compared to the plant height. The indicator was measured at 20 plants when $50 \%$ of the population was in the anthesis period. Stem diameter $(\mathrm{cm})$ : measured at the stem before the stem node where the first cob grows. The measurement was conducted after $50 \%$ of the population was in the anthesis period (the flower blooms perfectly).

\section{Leaf characteristics}

The number of leaves: the total number of leaves in a single maize plant was counted. The measurement was conducted after the plant flowers have bloomed. The number of leaves on top of the top cob: the number of leaves (including at the cob) was counted. The measurement was conducted at least on the average of 20 plants. Leaves length: measured from the node of the leaves up to the leaves tip. The leaves measured were on the top of the top cob, if the plant has more than one cob. Leaves width: measured at the same leaves that were measured for leaves length. The width was measured from the center point of the leaf's length. Leaves tip shape: the shape of the tip of the leaves was observed by employing the following criteria: (i) Acuminate $\left(<45^{\circ}\right)$; (ii) Acute $\left(45^{\circ}-90^{\circ}\right)$; (iii) Rounded; (iv) Truncate. The angle between leaf blade and stem: observed from the axillary bud position located at the leaves on top of the top cob, if the plant has more than one cob, with criteria as follows: (i) Very small $\leq 5^{\circ}$; (ii) Small $\pm 25^{\circ}$; (iii) Moderate $50^{\circ}$; (iv) Large $75^{\circ}$, (v) Very Large $\geq 90^{\circ}$. Index of leaf bone: counted by dividing the number of leaf bones with leaves.

\section{Characteristics of flowers and seeds}

Length of panicles: measured from the center point where the bottom panicle branch sticks up to the spike tip. The measurement was conducted after the plant was in the close-to-ripeness phase after anthesis. Length of the flower stalk $(\mathrm{cm})$ measured at a distance between the top node under the flag leaf and the lowest panicle branch. The measurement was conducted after the plants were close to ripeness/after anthesis. Panicle branch distance $(\mathrm{cm})$, the distance was measured between the tip of the male flower stalk and the first panicle branch. Male blossoming age is calculated when at least $50 \%$ of the plants are fully blossoming. Blossoming age of females, calculated when at least $50 \%$ of the plants have shed silk on their cobs. The color of the stems, observed on the stems that are located between the top two cobs if the maize has more than one cob. The observation was conducted when the plants were fully blooming. Type of panicle, observed in the presence of panicle branches, with the following criteria: (i) Primary; (ii) Primary-secondary; (iii) Primary-secondary-tertiary.

Cob length $(\mathrm{cm})$ is calculated from the length of the cobs to the ends. Measurements were made on corn without husks. The diameter of the cobs $(\mathrm{cm})$ is calculated at the center of the cobs. Weight of the cob with weight ( $\mathrm{kg} / \mathrm{cobs})$, calculated from the weight of the cobs with husks after drying the corn. Type of seeds expressed up to three types of seeds according to the frequency, with the following criteria: (i) flour; (ii) semi flour with a hard endosperm outer layer; (iii) horse tooth shape; (iv) semi horse tooth shape, between horse tooth and pearl but closer to horse tooth shape; (v) semi pearl, pearl with soft tip; (vi) pearls; (vii) popcorn; (viii) sweet corn; (ix) Opaque 2 (QPM); (x) sticky rice; (xi) Corn Pod. Seed color, expressed up to three kinds of seeds according to their 
frequency, with the following criteria: (i) white, (ii) yellow; (iii) purple; (iv) varying color; (v) chocolate; (vi) orange; (vii) striped; (viii) white tip; (ix) red. Amounts of seeds per row counted the number of seeds per row. Weight per 1000 kernels (grams), the weight of 1000 kernels was measured after dried by converting to the water content at $10 \%$

\section{Analysis of nutritional values}

The nutritional value of maize was analyzed by using proximate analysis for the ash content, protein content, fat content, and carbohydrate content. A sample of $500 \mathrm{~g}$ of maize was tested for proximate at the Laboratory of the Bogor Agricultural Products Harvesting Center using the Indonesian National Standard and AOAC analysis methods as follows:

\section{Ash content analysis (SNI 01-2891-1992)}

A total of 2-3 $\mathrm{g}$ of the sample was weighed into a known weight porcelain (or platinum) dish, and then charred over a Bunsen burner. It was then heated in an electric furnace with a maximum temperature of $550^{\circ} \mathrm{C}$ until the ascending process was completed (the furnace door is slightly opened to allow oxygen to enter). After that, the sample was cooled in an excavator and weighed until the fixed weight was shown.

$$
\begin{aligned}
& \text { Ash content }=\frac{\mathrm{W}_{1}-\mathrm{W}_{2}}{\mathrm{~W}} \times 100 \% \\
& \text { Where: } \\
& \mathrm{W}: \text { sample weight before ashed }(\mathrm{g}) \\
& \mathrm{W}_{1}: \text { sample weight and container after ashed }(\mathrm{g}) \\
& \mathrm{W}_{2} \text { : weight of empty container }(\mathrm{g})
\end{aligned}
$$

\section{Analysis of crude protein level (AOAC 2001)}

$0.1 \mathrm{~g}$ of sample was mixed with $1 \mathrm{~g}$ of catalyst (made by mixing $1 \mathrm{~g}$ of $\mathrm{CuSO}_{4}$ and $1.2 \mathrm{~g}$ of $\mathrm{NaSO}_{4}$ ) and $2.5 \mathrm{~mL}$ of concentrated $\mathrm{H}_{2} \mathrm{SO}_{4}$, then boiled in a Kjedhahl flask until clear. The mixture was then cooled and diluted to 100 $\mathrm{mL}$. A total of $5 \mathrm{~mL}$ of sample was put into the distillation device and the distillation process was stopped when the volume of the distillate has reached twice the volume before distillation. The distillate was then titrated with 0.02 $\mathrm{N} \mathrm{NaOH}$ and 2 drops of the Mengsel indicator were added. The same treatment was also conducted with blanks.

Protein level $=\underline{\mathrm{mL} \text { titration (blank-titration) } \times \mathrm{N} 14.007 \times 6.25} \times 100 \%$ Sample weight $(\mathrm{g}) \times 1000$

\section{Analysis of crude fat level (SNI 01-2891-1992)}

1-2 $\mathrm{g}$ of the sample was weighed and then put in a paper sleeve which has been covered with cotton. The paper sleeve containing the sample was clogged with cotton and dried in an oven with a temperature of not more than $80^{\circ} \mathrm{C}$ for approximately 1 hour. The sample was then inserted into a Soxhlet tool that has been connected to a fat flask filled with boiling stone which has been dried and its weight is known. The sample was then extracted with hexane or with other fat solvents for approximately 6 hours, then the hexane was distilled, and the fat extract was dried into a drying oven at $105^{\circ} \mathrm{C}$. The sample was then weighed after being dried in the oven and cooled. The drying process was repeated until a fixed weight is reached.

$\%$ fat $=\frac{\mathrm{W}-\mathrm{W}_{1}}{\mathrm{~W}_{2}} \times 100 \%$

Where:

$\mathrm{W}$ : sample weight $(\mathrm{g})$

$\mathrm{W}_{1}$ : sample weight before extraction $(\mathrm{g})$

$\mathrm{W}_{2}$ : weight of fat flask after extraction $(\mathrm{g})$.

Analysis of carbohydrate level (SNI 01-2891-1992)

A total of $5 \mathrm{~g}$ sample was weighed then put in $500 \mathrm{~mL}$ of Erlenmeyer flask. An amount of $200 \mathrm{~mL}$ of $3 \% \mathrm{HCl}$ solution was added into the sample and boil it for 3 hours using an upright cooler. Afterward, the solution was cooled and neutralized with $30 \% \mathrm{NaOH}$ solution (using litmus or phenolphthalein), and $\mathrm{CH}_{3} \mathrm{COOH} 3 \%$ was added so that the atmosphere of the solution becomes slightly acidic. The mixture contents were then transferred into a $500 \mathrm{~mL}$ volumetric flask and squeezed to the line mark. A total of $10 \mathrm{~mL}$ was filtered and poured into a $500 \mathrm{~mL}$ Erlenmeyer flask, added with $25 \mathrm{~mL}$ of luff solution (using a pipette), a few boiling bolts, and $15 \mathrm{~mL}$ of distilled water. The mixture was then heated with a steady fire and brought to a boil within 3 minutes (using a stopwatch) and boil it continuously for exactly 10 minutes (counting from the moment it starts to boil), then quickly cooled down in a tub filled with ice. After cooling, $15 \mathrm{~mL}$ of $20 \% \mathrm{KI}$ and $25 \mathrm{~mL}$ of $25 \% \quad \mathrm{H}_{2} \mathrm{SO}_{4}$ were added slowly. The solution was immediately titrated with $0.1 \mathrm{~N}$ Tio solution (using the instructions for $0.5 \%$ starch solution); afterward, the blank was filled.

Glucose rate $=\underline{\mathrm{W}}_{\underline{\mathrm{W}}} \underline{\mathrm{ffp}} \times 100 \%$

Where:

Carbohydrate rate $=0.90 \times$ glucose rate

$\mathrm{W}_{1}$ : sample weight $(\mathrm{g})$

$\mathrm{W}_{2}$ : contained glucose for each $\mathrm{ml}$ of Tio solution used from the list

$\mathrm{fp}$ : dilution factor

\section{Data analysis}

The data of morphological characteristics were described according to the appearance of each plant organ observed in the field; the plant was then scored by referring to the descriptor guidelines. Further, a descriptive analysis was applied to scrutinize the nutritional value of binthe kiki maize variety.

\section{RESULTS AND DISCUSSION}

\section{Morphological characteristics of binthe kiki maize variety}

The local binthe kiki maize variety has the following morphological characteristics as shown in Table 1 and Figure 2. The height of binthe kiki maize variety is relatively shorter compared to the local waxy corn cultivars of 
Batarakamu and Batarakoasa from South Sulawesi whose stem height ranges from 198-224 cm (Wawo et al. 2019b).

The stems of the plant are cylindrical and dominantly green, with weak anthocyanin staining near the stem internodes; the average circumference of the stem is $6.35 \mathrm{~cm}$, similar to the stem circumference of Srikandi Putih maize (Wulandari and Sularno 2016), but smaller than the Momala variety which has an average stem circumference of $8.46 \mathrm{~cm}$ (Suleman et al.2019). The green color of binthe kiki plant's stalk is similar to one of the local maize originating from Kisar Island, Maluku (Sinay and Karuwal 2018).

The width of the binthe kiki corn leaves is in the narrow category $(5.1-7 \mathrm{~cm})$. The width of the leaves is categorized from very narrow $(<5 \mathrm{~cm})$, narrow $(5.1-7 \mathrm{~cm})$, medium $(7.1-9 \mathrm{~cm})$, wide $(9.1-11 \mathrm{~cm})$, up to very wide $(>11 \mathrm{~cm})$. The type of leaves is affected by the leaf angle. The angle of the leaves and the shape of the tip of the corn also vary, from very small to very large (IBPGR 1991). The leaf width of binthe kiki variety is narrower compared to that of the local variety of Pena Molo, Pena Fatu, Pena Boto, and Pena Kikis originating from North Central Timor, East Nusa Tenggara ranging from 7.5-9.1 cm (Bani 2018).

The orange color of binthe kiki variety is assumed to be high in beta-carotene and anthocyanin. As the findings suggest, the quantitative character of seed color can provide information about the content of beta-carotene and anthocyanin which is closely related to the color of the kernels of the plant. The clusters of maize have yellow to bright red color characteristics. An imaging technology approach has consistently quantified the color of corn based on the parameters RGB, R, G, and B. The quantification results for the beta-carotene and anthocyanin study populations function to distinguish each maize based on its color density. Brightly colored maize varieties will have high RGB, R, G, and B values, while darker varieties will have lower values (Nurholis et al. 2020).

\section{Nutritional values of binthe kiki variety}

The analysis results of the proximate contents of binthe kiki variety are presented in Table 2 . The data were obtained from an average of two repetitions. The water and fat contents of binthe kiki variety are lower than the yellow Manado maize kernels. On the other hand, the binthe kiki variety has higher ash content, fiber content, and protein content compared to the yellow Manado variety. A study by Landeng et al. (2017) on yellow Manado maize reported that the moisture content of the variety is at $12.62 \pm 0.31 \%$, ash news at $2.20 \pm 0.01 \%$, protein content at $7.71 \pm 0.03 \%$, fiber content at $2.76 \pm 0.74 \%$, and fat content at $6.09 \pm 0.02 \%$.
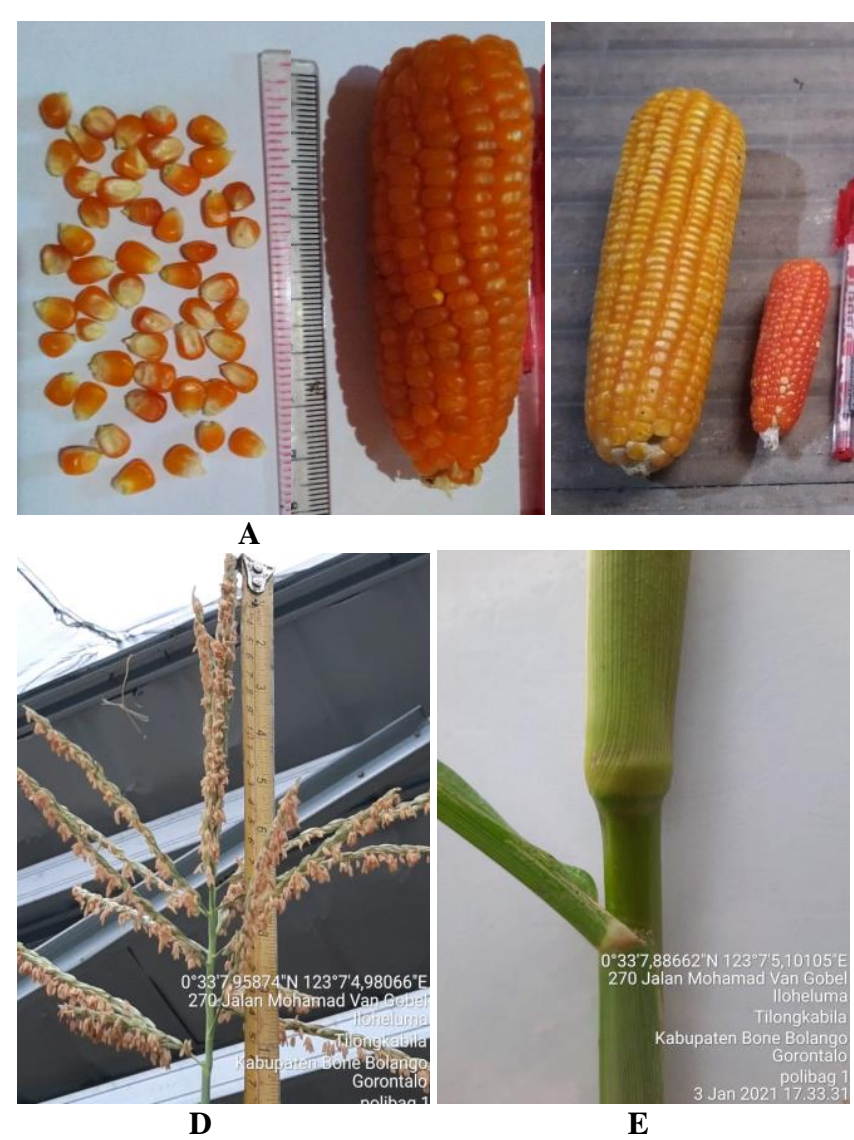

$\mathbf{E}$

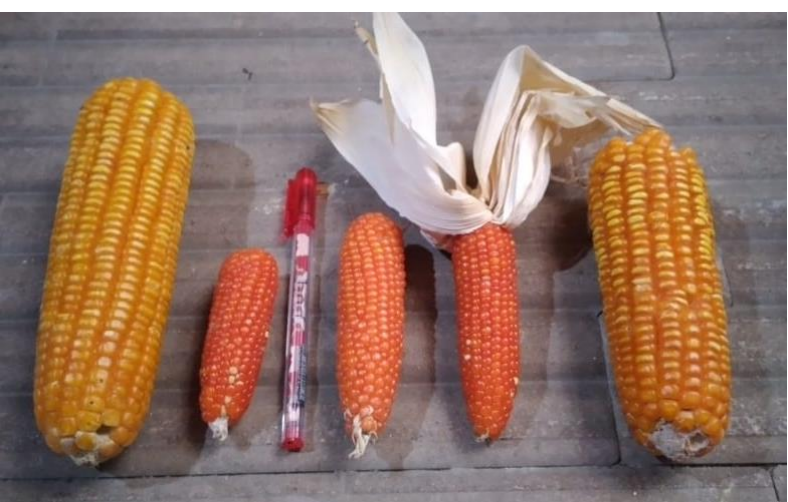

B

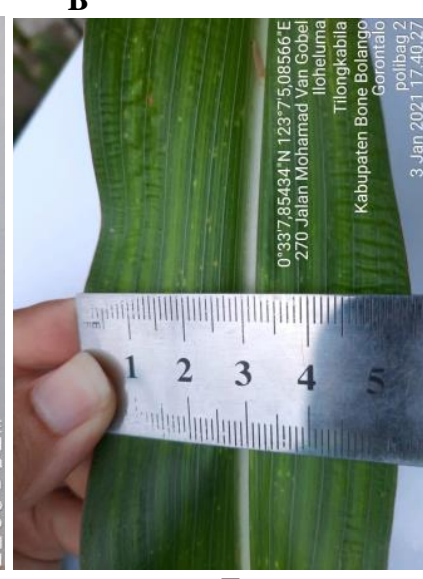

$\mathbf{F}$

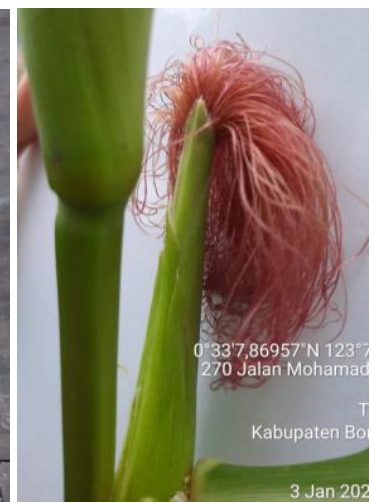

C

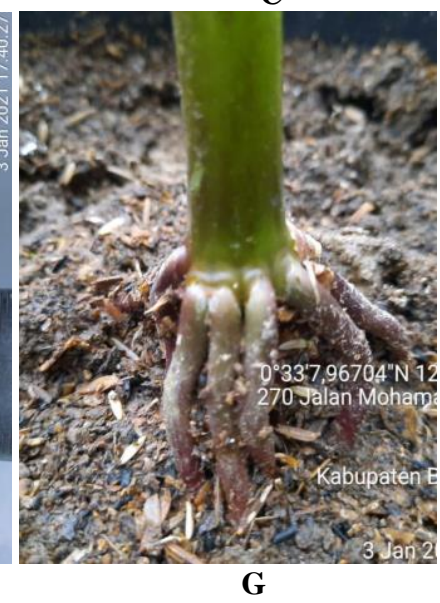

Figure 2. Description of binthe kiki maize variety: A. Corn kernels and cob, B. Comparison between cob of binthe kiki and Bisi-18 hybrid variety, C. Silk of binthe kiki, D. Male flower of the plant (anther), E. Stem and internodes, F. Leaves, G. Roots

Furthermore, the carbohydrate content in binthe kiki maize is higher compared to that of the local varieties of 
Momala and Tunu 'ana maize (see Table 2). However, the maize's carbohydrate content is still lower than that of Gumarang variety. The findings by Murningsih et al (2018) indicate that Tunu 'ana and Gumarang maize have carbohydrate values of $70.69 \pm 0.21 \%$ and $76.35 \pm 0.33 \%$, respectively. Binthe kiki has a higher carbohydrate than that of Momala variety; as shown by a previous study, the Momala variety has a carbohydrate content of $68.16 \pm 0.43 \%$ (Kandowangko et al. 2020).

\section{Potentials of binthe kiki maize variety}

Compared to other varieties, Binthe kiki maize is superior in terms of sweetness taste due to the total sugar content at $3.37 \pm 0.043$ and reduced sugar content at $1.85 \pm 0.025$ (Table 2). The community treats the maize as one of the key ingredients of traditional dishes, such as in binthe biluhuta or Gorontalese corn soup and balobinthe corn rice. Moreover, the amylose contents in binthe kiki are at $22.00 \pm 0.068 \%$ (Table 2). Amylose is the main factor affecting the quality of food ingredients. For instance, a rice variety that is low in amylose will be soft and sticky. Conversely, if the amylose content is high, the rice becomes hard and not sticky. The amylose content in local binthe kiki maize is lower than the amylose content in rice varieties originating from lowland rice in West Sumatra which ranges from 27.2\%-28.5\%. (Anhar 2011). Amylose content in food ingredients is classified into low $(<20 \%)$, moderate $(20-24 \%)$, and high $(>25 \%)$. As based on the classification, the binthe kiki variety has moderate amylose content. Amylose content plays a significant role in starch retrogradation and texture properties of rice. Rice with a high amylose content is easier to retrograde, and vice versa. In addition, amylose content is also significant in rehydration time the higher the amylose level, the faster the rehydration time. According to Luna et al (2015), amylose contents are influenced by the variety of instant rice raw materials (Luna et al. 2015).

On top of that, binthe kiki maize is low water content, only at $7.60 \%$ (Table 3 ); it easily becomes dry when exposed to the sun. Additionally, this maize breed is solid, durable (even if stored for months), and resistant to plant hopper pests. Such characteristics are the variety's potentials for the community to treat it as the main staple during the drought period.

The binthe kiki variety tends to have s shorter plant height and smaller leaf width compared with the previously reported findings on the same variety originating from Wonosari Sub-district, Boalemo District, Gorontalo Province (Center for Plant Variety Protection and Licensing 2018). On top of that, the study discovers a difference in the blooming time of the male flowers and the time when the silk comes out from the cob. As based on the findings, $50 \%$ of male flowers bloom at the 51st days after planting (DAP), while the appearance of female flowers and silk outside the cob is at 53rd DAP. The period is longer than that of previously reported findings at 35-40th DAP. Such results may be due to environmental factors. Plant size and leaf area determine the interception of sunlight in the plant canopy; it can affect the photosynthesis process and overall maize yield (Huang et al. 2017). Therefore, further studies should take into account the potential effects of fertilization interventions to increase the maize yield more carefully, particularly that of binthe kiki variety.

Table 1. Morphological characteristics of binthe kiki maize variety

\begin{tabular}{|c|c|}
\hline Parameters & Average \\
\hline \multicolumn{2}{|l|}{ Habitus } \\
\hline Plant height $(\mathrm{cm})$ & 161 \\
\hline The location of the top cob $(\mathrm{cm})$ & 119 \\
\hline $\begin{array}{l}\text { The ratio of the height of the top } \\
\text { cob to the plant height }\end{array}$ & $161 / 119$ \\
\hline \multicolumn{2}{|l|}{ Stem } \\
\hline Stem circumference $(\mathrm{cm})$ & 6.35 \\
\hline Stem color & $\begin{array}{l}\text { green and slightly brownish } \\
\text { near the stem segment }\end{array}$ \\
\hline \multicolumn{2}{|l|}{ Leaves } \\
\hline Number of leaves (plant) & 12 \\
\hline Blade length $(\mathrm{cm})$ & 71.12 \\
\hline Leaf width $(\mathrm{cm})$ & 5.21 \\
\hline Leaf bone index & 16 \\
\hline Leaf tip shape & pointed \\
\hline The direction of the leaf blade & slightly curved \\
\hline $\begin{array}{l}\text { The angle between the leaf blade } \\
\text { and the stem }\end{array}$ & relatively small $\left( \pm 25^{\circ}\right)$ \\
\hline \multicolumn{2}{|l|}{ Flowers } \\
\hline Long panicles $(\mathrm{cm})$ & 26.3 \\
\hline $\begin{array}{l}\text { The length of the male flower } \\
\text { stalk }(\mathrm{cm})\end{array}$ & 33.5 \\
\hline $\begin{array}{l}\text { Distance between panicle } \\
\text { branches }(\mathrm{cm})\end{array}$ & 8.5 \\
\hline Male flowers bloom (DAP) & 51 \\
\hline Female flowers bloom (DAP) & 53 \\
\hline Length of cobs $(\mathrm{cm})$ & 8.4 \\
\hline Diameter of cobs $(\mathrm{cm})$ & 2.74 \\
\hline The type of panicles & Primary-secondary \\
\hline Weight of cob $(\mathrm{Kg} / \mathrm{cob})$ & 0.060 \\
\hline Weight of husk-less cob (kg/cob) & 0.054 \\
\hline Corn cob hair color & $\begin{array}{l}\text { has a very strong } \\
\text { anthocyanin coloring }\end{array}$ \\
\hline \multicolumn{2}{|l|}{ Seed } \\
\hline Type of seed & pearl-type \\
\hline Color of seed & Orange \\
\hline Number of seeds per row (seed) & 24 \\
\hline Number of seed rows per cob (rows & 16 \\
\hline 1000 grain weight (g/plant) & 145 \\
\hline
\end{tabular}

Table 2. Composition of binthe kiki proximate

\begin{tabular}{lll}
\hline \multicolumn{1}{c}{ Proximate composition } & Method & Binthe kiki \\
\hline Water content $(\%)$ & Gravimetric & $7.60 \pm 0.043$ \\
Ash content $(\%)$ & Gravimetric & $2.48 \pm 0.026$ \\
Fat content $(\%)$ & Soxhlet & $4.24 \pm 0.068$ \\
Protein content $(\%)$ & Kjeldahl & $12.53 \pm 0.057$ \\
Carbohydrate $(\%)$ & By different & $73.15 \pm 0.059$ \\
Crude fiber $(\%)$ & Gravimetric & $7.68 \pm 0.042$ \\
Reduction sugar $(\%)$ & Titration & $1.85 \pm 0.025$ \\
Amylose $(\%)$ & Spectro & $22.00 \pm 0.068$ \\
Total sugar $(\%)$ & Titration & $3.37 \pm 0.043$ \\
\hline
\end{tabular}


Table 3. Comparison of proximate contents of binthe Kiki variety and other varieties

\begin{tabular}{lcccc}
\hline Proximate composition & Binthe kiki & Momala ${ }^{1)}$ & Pena tunu 'ana' 2) & Gumarang $^{\text {2) }}$ \\
\hline Water content (\%) & $7.60 \pm 0.043$ & - & $10.49 \pm 0.01$ & $11.43 \pm 0.04$ \\
Ash content (\%) & $2.48 \pm 0.026$ & $2.39 \pm 0.66$ & $1.45 \pm 0.01$ & $1.21 \pm 0.11$ \\
Crude fat (\%) & $4.24 \pm 0.068$ & $4.64 \pm 0.11$ & $5.59 \pm 0.22$ & $4.15 \pm 0.17$ \\
Protein (\%) & $12.53 \pm 0.057$ & $9.56 \pm 0.66$ & $11.78 \pm 0.05$ & $6.88 \pm 0.01$ \\
Carbohydrate (\%) & $73.15 \pm 0.059$ & $68.16 \pm 0.43$ & $70.69 \pm 0.21$ & $76.35 \pm 0.33$ \\
Crude fiber (\%) & $7.68 \pm 0.042$ & - & $6.84 \pm 0.07$ & $4.82 \pm 0.14$ \\
\hline
\end{tabular}

Note: 1. Proximate composition of Momala variety (Kandowangko et al. 2020); 2. Proximate composition of Pena Tunu'ana variety (Murningsih et al. 2018)

In conclusion, the findings suggest that the most prominent characteristic of binthe kiki is the smaller size of the cob and kernels, about one-third the size of other typical maize varieties. The variety is rich in protein and carbohydrate and low in fat; it has moderate amylose contents. As based on the discussion, efforts to conserve and develop the binthe kiki local maize variety are of significance to support food resilience and self-sufficiency measures within the community.

\section{ACKNOWLEDGEMENTS}

The study was supported financially by the Non-tax State Revenue of Universitas Negeri Gorontalo, Indonesian in the mechanism of Development of Professors Competence with Contract No. B/58/UN47.D1/PT.01.03/2020.

\section{REFERENCES}

AOAC. 2001. AOAC Guidelines for Single Laboratory. Https://www.aoac.org/aoac_prod_imis/AOAC

Budiarti SG, Silitonga TS, Somantri IH. 2004. The Guide characterization on corn plants (Translated). Kasim F, Sutoro, Orbani (Eds.). Komisi Nasional Plasma Nutfah. Badan Penelitian dan Pengembangan Penetian, Departemen Pertanian, Jakarta. [Indonesian]

Dahlan M. 2018. The formation and production of free-seeded seeds. Balai Penelitian Tanaman Serealia, Maros. [Indonesian]

Hwang T, Ndolo VU, Katundu M, Nyirenda B, Bezner-Kerr R, Arntfield S, Beta T. 2016. Provitamin A potential of landrace orange maize variety (Zea mays L.) grown in different geographical locations of central Malawi. Food Chem 196: 1315-1324.

IBPGR, 1991. Descriptors for Maize. International Maize and Wheat Improvement Center. Mexico City. International Board for Plant Genetic Resources, Rome

Kahiu N, Jerono C, Muchira C, Chemining'wa G. 2013. Anthesis to silking interval usefulness in developing drought-tolerant maize. J Renew Agric 1: 84-90.
Kandowangko NY, Solang M, Retnawaty E. 2020. Traditional agromanagement practices, utilization and nutritional composition of momala: A local maize variety of Gorontalo, Indonesia. Biodiversitas 21 (3): 853-859.

Karigidi KO, Olaiya CO. 2019. Antidiabetic activity of corn steep liquor extract of Curculigo pilosa and its solvent fractions in streptozotocininduced diabetic rats. J Trad Compl Med 10 (6): 555-564.

Landeng PJ, Suryanto E, Momuat LI. 2017. The composition proximate and potential antioxidants from seed corn manadonesse yellow variety (Zea mays, L.). Chem Progr 10 (1): 36-44. [Indonesian]

Luna P, Herawati H, Widowati S, Prianto AB. 2015. Effect of amylose content on physical and organoleptic characteristics of instant rice. Jurnal Penelitian Pascapanen Pertanian 12 (1): 1-10. [Indonesian]

Murniningsih T, Yulita KS, Bora CY, Adwita Arsa IGB. 2018. Proximate and mineral content of maize landrace (tunu ána' ) from East Nusa Tenggara. Prosiding Seminar Nasional Masyarakat Biodiversitas Indonesia 5: 107-111. [Indonesian].

Nurholis N, Syafii M, Khoiri S. 2020. Study of the color of seed local maize variety of Madura using imaging technology. Agrovigor: Jurnal Agroekoteknologi 13 (1): 60 -69. [Indonesian]

Peraturan Daerah Provinsi Gorontalo. 2015. Gorontalo provincial regulation No. 3 of 2015 concerning Food-based Nutrition Science Learning Vol. 151. [Indonesian]

Pusat Perlindungan Varietas dan Perijinan Tanaman. 2018. Official News Registration of corn local variaty binte kiki. PPVPT, Jakarta. [Indonesian]

Suleman R, Kandowangko NY, Abdul A. 2019. Morphological characterization and proximate analysis of maize varieties Momala Gorontalo. J Jambura Edubiosfer 1 (2): 72-81. [Indonesian]

Suarni, Widowati S. 2017. Structure, composition and nutrition of maize. In Corn: Technique of production and development. Balai Penelitian Tanaman Serealia, Maros. [Indonesian]

Wawo AH, P Lestari, N Setyowati. 2019. Exploration of local corn in South Sulawesi and study of its growth at the Research Center for Biology, LIPI, Cibinong. J Biota 4 (2): 79-93. [Indonesian]

Yasin MH, Singgih S, Hamdani, Santoso SB. 2017. Biodiversity of Corn Germplasm. In Corn: Technique of Production and Development. Balai Penelitian Tanaman Serealia, Maros. [Indonesian]

Yasin HG, Isnaeni M, Andayani NN, Faisal. 2018. Genetik improvement and yield evaluation of germplasm corn variety corn red "Messi". Buletin Penelitian Tanaman Sereal 2 (2): 1-6. [Indonesian]

Yusran, Maemunah. 2011. Morphology characterization of glutinous corn varieties in Ampana Kota Sub Sub-district of Tojo Una-Una District. J Agroland 18 (1): 36-42. 